\title{
Influence of addition of cobalamin to the extender on the post-thaw motility, viability, and DNA integrity of bovine ejaculate
}

\author{
ALICJA MIZERA, MARIAN KUCZAJ, ANNA SZUL*, JAROSŁAW JĘDRASZCZYK* \\ Institute of Animal Breeding, Faculty of Biology and Animal Science, \\ Wrocław Univeristy of Environmental and Life Sciences, Chełmońskiego 38C, 51-630 Wrocław \\ *Małopolskie Centrum Biotechniki Sp. z 0.0., Krasne 32, 36-007 Krasne
}

\section{Mizera A., Kuczaj M., Szul A., Jędraszczyk J. \\ Influence of addition of cobalamin to the extender \\ on the post-thaw motility, viability, and DNA integrity of bovine ejaculate \\ Summary}

The present study was undertaken to investigate the effect of various concentrations of cobalamin (vitamin $B_{12}$ ) in Bioexcell ${ }^{\circledR}$ extender on the spermatozoa quality of Simmental bulls. The semen was collected from 12 bulls by means of an artificial vagina. Vitamin $B_{12}$ at concentrations of $1.50,2.50,3.50$, and $5.00 \mathrm{mg} / \mathrm{mL}$ was added to bovine Bioexcell ${ }^{\circledR}$ extender. The semen aliquots were cooled and preserved at $4^{\circ} \mathrm{C}$. Their quality was evaluated during pre-freezing, and then the cooled semen samples were packaged into $0.25 \mathrm{ml}$ straws. The straws were frozen in the vapor of liquid nitrogen, and stored at $-196^{\circ} \mathrm{C}$ in a container. The straws were thawed one day later, and the characteristics of spermatozoa were examined. The results showed that the effect of vitamin $B_{12}$ on the viability, DNA fragmentation and motility of spermatozoa was significant under both preand post-freezing conditions $(p<0.05)$, and revealed that supplementation of the extender with $B_{12}$ improved the post-thaw spermatozoa quality in bulls.

Keywords: bovine, DNA, semen freezing, spermatozoa, vitamin B12

The use of artificial insemination with cryopreserved semen in cattle greatly advances animal breeding and production, reducing its costs and facilitating the distribution of semen (3). A major cause of the poor quality of buffalo bull semen and the low fertility of frozenthawed semen is cryocapacitation-inflicted damage to sperm during freezing and thawing (2). Spermatozoa are significantly affected by interactions of extracellular and intracellular fluid, sugars, proteins, salts of individual microelements, and other substances, whose concentration increases simultaneously with the osmotic pressure after ice crystal formation (33). Cold shock caused by the action of low temperatures on spermatozoa during the freezing process may damage mitochondria (28), plasma, and the acrosomal membrane of spermatozoa (24), inducing changes in the lipid composition or in the integrity and permeability of plasma and membranes (20).

Vitamin $\mathrm{B}_{12}$ (cobalamin) is a large, complex molecule responsible for a range of functions within the body. In biochemical reactions, vitamin $\mathrm{B}_{12}$ acts as a coenzyme (22). Moreover, it is a form usually used in vitamin supplements because of its stability. It has been demonstrated in experiments with rats that atrophic changes and the arrest of spermatogenesis resulted from a vitamin $\mathrm{B}_{12}$ deficiency. Watanabe et al. (32) observed that a deficiency of vitamin $B_{12}$ resulted in a decreased motility and velocity of sperm in male rats, as well as in an increased incidence of abnormal sperm. Research by Boxmeer et al. (5) showed that there was a positive correlation between the total cyanocobalamin concentration in seminal plasma and the spermatozoa concentration in semen. Cyanocobalamin is also known for its antioxidative potential, because, as a supplement, it decreases the amount of reactive oxygen species (ROS) produced during oxidative stress in human semen $(8,9)$. It has been suggested that vitamins $\mathrm{B}_{1}, \mathrm{~B}_{6}$, and $\mathrm{B}_{12}$ in rams play a key role in the thermoregulation of scrotal skin and rectal temperature and in maintaining libido, semen quality, and fertility during heat stress (10).

DNA sequences are involved in regulating the expression of genetic information. Sperm DNA integrity is important for the success of natural and assisted 
fertilization, including normal development of the embryo, fetus, and offspring (25). Semen cryopreservation is a fundamental technique for the conservation of genetic resources in cryobanks used for artificial insemination. Gual-Frau et al. (13) and Ni et al. (26) reported that vitamin $B_{12}$ had a positive effect on DNA integrity in human semen.

The physiological role and biological significance of vitamin $B_{12}$ in the cryopreservation of spermatozoa have not been sufficiently clarified. Hitherto, little has been published on the effect of vitamin $\mathrm{B}_{12}$ on the semen quality in bulls. Research on the effects of vitamin $B_{12}$ on bovine sperm has often been conducted using conventional methods, rather than modern semen quality evaluation techniques. Consequently, the results are still not sufficiently accurate. In the evaluation of the effects of vitamin $B_{12}$ on the quality of frozen spermatozoa, the role of vitamin $\mathrm{B}_{12}$ during semen freezingthawing is very important. Accordingly, the aim of this study was to evaluate the effects of supplementing the bovine sperm extender with vitamin $\mathrm{B}_{12}$ at various concentrations on the quality of spermatozoa after the cooling and freezing-thawing process.

\section{Material and method}

The present experiments were performed as part of routine activities during semen production at a reproductive station and did not require the approval of the ethics committee. The experiments were performed at the breeding and insemination centre Małopolskie Centrum Biotechniki Sp. z.o.o. (Krasne, Poland). In this study, twelve Simmental bulls with an average age of $3.5 \pm 0.5$ years were housed individually in pens. From each bull, seven ejaculates were collected using an artificial vagina at $7 \mathrm{a} . \mathrm{m}$. The semen was held in a water bath at $37^{\circ} \mathrm{C}$, while the sperm concentration and initial percentage of motile sperm were being estimated. The sperm concentration was assessed with a digital photometer (Dr Lange, LP 300 SDM; Minitube, Tiefenbach b. Landshut, Germany) at $560 \mathrm{~nm}$.

Semen processing. Semen samples were transferred into graduated test tubes immediately after collection and placed in a water bath at $37^{\circ} \mathrm{C}$. The fresh undiluted semen was then microscopically (Nikon E 200, China) evaluated for mass motility, percentage of motile sperm, progressive motility, viability, and abnormal spermatozoa. Semen samples that showed more than $80 \%$ motility and $60 \%$ viability were selected for the experiment. The semen was extended with the animal protein-free commercial BIOXcell ${ }^{\circledR}$ extender (IMV Technologies, L'Aigle, France) to a final concentration of $120 \times 10^{6}$ spermatozoa $/ \mathrm{mL}$.

After a positive evaluation, the semen samples were pooled to eliminate individual differences. The fresh semen was then divided into 5 equal fractions. One fraction was left for the control group (without vitamin $\mathrm{B}_{12}$ ), and vitamin $\mathrm{B}_{12}$ (ScanVet, Poland) at concentrations of 1.50, 2.50, 3.50, or $5.00 \mathrm{mg} / \mathrm{ml}$ was added to the other fractions. The semen was automatically packed (Bloc Machine FIN, IS 4, France) into polyvinyl chloride (PVC) straws $(0.25 \mathrm{~mL})$ (Biovet, France) filled and equilibrated for $1.5 \mathrm{~h}$ at $4^{\circ} \mathrm{C}$. After equili- bration, the straws were frozen in liquid nitrogen vapor using a computer-controlled automatic freezer at the rate of $-3^{\circ} \mathrm{C} / \mathrm{min}$ from $4^{\circ} \mathrm{C}$ to $-15^{\circ} \mathrm{C}$ and at the rate of $-10^{\circ} \mathrm{C} /$ min from $-15^{\circ} \mathrm{C}$ to $-80^{\circ} \mathrm{C}$ (IMV Technologies, France).

After reaching $-80^{\circ} \mathrm{C}$, the semen straws were plunged in liquid nitrogen and packaged in plastic goblets for 24 hours of storage in a liquid nitrogen container. After one day, the straws were thawed in a water bath at $38^{\circ} \mathrm{C}$ for $20 \mathrm{sec}$, and then the motility, progressive motility, viability and normality/abnormality of the semen were examined.

Volume. The volume of ejaculate was measured by reading graduated tubes (4).

Assessment of sperm DNA integrity. To further analyze the integrity of sperm DNA, chromatin susceptibility to acid-induced denaturation in situ was assessed. Chromatin instability was then quantified by flow cytometry (CytoFlex Beckman Coulter, B3-R1-V0, China) using the Sperm Chromatin Structure Assay (SCSA) test. The samples were thawed in a water bath $\left(26^{\circ} \mathrm{C}\right.$ for $\left.30 \mathrm{sec}\right) .13 \mu \mathrm{L}$ of semen and $487 \mu \mathrm{L}$ of $\mathrm{NaCl}(0,9 \%)$ were placed in a glass tube on ice. $50 \mu \mathrm{L}$ of the mixture thus prepared was moved to another tube on ice, and $100 \mu \mathrm{L}$ of acid detergent solution $(0.08 \mathrm{M} \mathrm{HCl}, 0.15 \mathrm{M} \mathrm{NaCl}, 0.1 \% \mathrm{v} / \mathrm{v}$ Triton X-100, $\mathrm{pH} 1.2)$ was added. After exactly $30 \mathrm{sec}$ (without light), $300 \mu \mathrm{L}$ of acridine orange (AO) staining solution was added $[6 \mu \mathrm{g}$ (chromatographically purified) AO (Polysciences, Inc. USA) per ml of citrate buffer $(0.037 \mathrm{M}$ citric acid, $0.126 \mathrm{M}$ $\mathrm{Na}_{2} \mathrm{HPO}_{4}, 1.1 \mathrm{mM}$ EDTA disodium, $0.15 \mathrm{M} \mathrm{NaCl}, \mathrm{pH}$ 6.0)]. Each sample was incubated for 3 minutes on ice (without light) and then examined by flow cytometry; 5000 spermatozoa were evaluated in each sample.

Sperm motility. Mass motility was examined in $20 \mu \mathrm{L}$ of semen, which was placed on a pre-warmed slide without a coverslip and analyzed under a microscope equipped with phase-contrast optics $(100 \times)(4)$. Mass motility was scored according to the following scale: + no motion, ++ free spermatozoa moving without forming any waves, +++ vigorous movement with moderately rapid waves, ++++ very rapidly moving waves. $15 \mu \mathrm{l}$ of semen was placed on a pre-warmed slide and covered with a coverslip. Semen motility was determined at a higher magnification $(400 \times)$ by an eye estimation of the percentage of spermatozoa moving progressively straight forward.

Computerized assessment. Sperm motility was examined using a Sperm Class Analyzer (SCA, version 5.1, Microptic, Barcelona, Spain), a light microscope (Nikon Eclipse E200) with a $\times 10$ negative phase objective, a Basler camera (scA 780-54fc, Ahrensburg, Germany), a warm stage, and a computer to analyze and save data. The following sets were used: medium VAP $-50.0 \mu \mathrm{m} \mathrm{s}-1$, low VAP $\mu 10 \mu \mathrm{m} \mathrm{s}-1$, low LIN $-50.0 \%$. Before analysis, semen was diluted $1: 10$ in a warm $\left(25^{\circ} \mathrm{C}\right)$ physiological solution (sodium chlorate $0.9 \%$ ). Then $2 \mu \mathrm{L}$ of the prepared sample was placed in a Leja 4 analysis chamber (Leja Products B.V., Holland) $20.0 \mu \mathrm{m}$ thick. The slide was mounted on a stage warmer set at $38^{\circ} \mathrm{C}$. The following motility parameters were examined: percentage of motile sperm, curvilinear velocity (VCL), straight-line velocity (VSL), path velocity (VAP), linearity (LIN), and amplitude of lateral head displacement (ALH). A minimum of 500 cells were evaluated, and 
depending on sperm concentration, two to four analyses were performed per sample.

Viability. The double stain SYBR-14 with propidium iodide (L-7011 LIVE/DEAD Sperm Viability Kit; Invitrogen, Molecular Probes, Barcelona, Spain) was used with a flow cytometer (CytoFlex Beckman Coulter, B3-R1-V0, China). To this end, $50 \mu \mathrm{L}$ of thawed semen was measured $\left(37^{\circ} \mathrm{C}\right.$ for 20 seconds), and $940 \mu \mathrm{L} \mathrm{NaCl}(0.9 \%)$ and $5 \mu \mathrm{L}$ SYBR-14 were added. These were thoroughly mixed and incubated $\left(36^{\circ} \mathrm{C}\right.$ for $\left.10 \mathrm{~min}\right)$ without light. Subsequently, $5 \mu \mathrm{L}$ of propidium iodide (PI) was remixed and incubated for 3 min without light, followed by a test.

Statistical analysis. Data are presented as mean \pm standard error of the mean (SEM). Analysis of variance (ANOVA) was used to assess differences between concentrations of vitamin $B_{12}$ supplementation on all semen characteristics. When the F ratio was significant $(p<0.05)$, Duncan's multiple range test was used to compare treatment means. The statistical analysis of the results was performed with Statistica 12.0 (StatSoft, Poland).

\section{Results and discussion}

The influence of vitamin $\mathrm{B}_{12}$ on the parameters of frozen/thawed semen from Simmental bulls is shown in Tables 1 and 2.

The highest motility $(72.71 \% \pm 5.04)$ was observed in the BIOXcell ${ }^{\circledR}$ extender containing $2.50 \mathrm{mg} / \mathrm{mL}$ of vitamin $\mathrm{B}_{12}$. The motility and VCL, VSL, VAP, LIN, STR and WOB values of the frozen-thawed sperm supplemented with $2.50 \mathrm{mg} / \mathrm{mL}$ vitamin $B_{12}$ were significantly higher than those for other concentrations $(\mathrm{p}<0.05)$. There was also a positive effect of vitamin $\mathrm{B}_{12}$ at $3.50 \mathrm{mg} / \mathrm{mL}$ on VSL, LIN, WOB, and ALH $(\mathrm{p}<$ $0.05)$. On the other hand, when the concentration of vitamin $B_{12}$ in the extender was increased to $5.00 \mathrm{mg} /$ $\mathrm{mL}$, sperm motion characteristics deteriorated significantly. Compared with the control, sperm motility and motion characteristics were improved in the presence of vitamin $B_{12}$ at a concentration of $2.50 \mathrm{mg} / \mathrm{mL}$.

The results of the tests of the viability and DNA integrity of frozen-thawed bovine sperm are shown in Table 2.

The percentages of DNAintact spermatozoa were significantly improved $(\mathrm{p}<$ 0.05 ) by supplementing with $1.50 \mathrm{mg} / \mathrm{mL}, 2.50 \mathrm{mg} / \mathrm{mL}$, and $3.50 \mathrm{mg} / \mathrm{mL}$ vitamin $B_{12}$. Higher concentrations (5.00 $\mathrm{mg} / \mathrm{mL}$ ) did not significantly Head Displacement cantly at $\mathrm{p}<0.05$ $(\mathrm{p}>0.05)$ affect DNA. In addition, sperm viability was not affected by the supplementation of 1.50, 3.50, and $5.00 \mathrm{mg} / \mathrm{mL}$ vitamin $\mathrm{B}_{12}$, but was significantly increased by the addition of $2.50 \mathrm{mg} / \mathrm{mL}$. A sperm viability analysis based on randomly selected graphs is shown in Figure 1. In part A of the figure, the graph presents the results of viability analysis for sperm without vitamin $\mathrm{B}_{12}$, whereas in part $\mathrm{B}$ the semen containing $2.50 \mathrm{mg} / \mathrm{mL}$ of vitamin $B_{12}$ is analyzed.

We investigated the effect of vitamin $B_{12}$ on the characteristics of sperm from Simmental bulls during the freezing-thawing process. The results indicate that the addition of $2.50 \mathrm{mg} / \mathrm{mL}$ of vitamin $\mathrm{B}_{12}$ to $\mathrm{BIOXcell}{ }^{\circledR}$ extender increased the motility and viability of semen, as well as protected its DNA from defragmentation. Our observations indicate that vitamin $\mathrm{B}_{12}$ protected spermatozoa under freezing conditions. Similar results were obtained by Ha and Zhao (14), who showed that extender supplemented with a vitamin B complex improved the quality of frozen-thawed semen during cryopreservation in rams. Asadpour et al. (1) reported that the addition of $2 \mathrm{mg} / \mathrm{mL}$ of vitamin $B_{12}$ to the extender increased sperm viability and motility, as well as the percentage of normal spermatozoa in the hypoosmotic swelling test (HOST), in Ghezel $\times$ Baluchi and Ghezel $\times$ Arkharmerino rams during storage at $5^{\circ} \mathrm{C}$. Jeyendran et al. (21) also noted that the HOST can be used to determine plasma membrane permeability and was shown to correlate with the numbers of spermatozoa undergoing capacitation. Hu et al. (18)

Tab. 1. Mean values of motility parameters of frozen-thawed bovine semen in the presence or absence of vitamin $B_{12}(\bar{x} \pm S D ; n=12)$ obtained by CASA

\begin{tabular}{|l|c|c|c|c|c|}
\hline \multirow{2}{*}{ Parameter } & \multirow{2}{*}{ Control } & \multicolumn{4}{c|}{ Vitamin $B_{12}$} \\
& & $1.5 \mathrm{mg} / \mathrm{mL}$ & $2.5 \mathrm{mg} / \mathrm{mL}$ & $3.5 \mathrm{mg} / \mathrm{mL}$ & $5.0 \mathrm{mg} / \mathrm{mL}$ \\
\hline Motility $(\%)$ & $54.68^{\mathrm{cd}} \pm 1.70$ & $57.23^{\mathrm{c}} \pm 4.97$ & $72.71^{\mathrm{a}} \pm 5.04$ & $61.41^{\mathrm{b}} \pm 4.17$ & $51.94^{\mathrm{d}} \pm 6.70$ \\
VCL $(\mu \mathrm{m} / \mathrm{s})$ & $62.90^{\mathrm{b}} \pm 1.00$ & $62.09^{\mathrm{b}} \pm 5.28$ & $73.91^{\mathrm{a}} \pm 0.53$ & $64.80^{\mathrm{b}} \pm 5.77$ & $40.97^{\mathrm{c}} \pm 2.69$ \\
\hline VSL $(\mu \mathrm{m} / \mathrm{s})$ & $42.02^{\mathrm{c}} \pm 0.95$ & $44.26^{\mathrm{bc}} \pm 4.61$ & $50.77^{\mathrm{a}} \pm 0.31$ & $47.10^{\mathrm{ab}} \pm 7.05$ & $25.61^{\mathrm{d}} \pm 4.15$ \\
VAP $(\mu \mathrm{m} / \mathrm{s})$ & $49.75^{\mathrm{bc}} \pm 0.97$ & $53.13^{\mathrm{ab}} \pm 4.96$ & $54.89^{\mathrm{a}} \pm 3.33$ & $48.15^{\mathrm{c}} \pm 3.79$ & $30.20^{\mathrm{d}} \pm 4.39$ \\
\hline LIN $(\%)$ & $62.93^{\mathrm{b}} \pm 0.97$ & $62.97^{\mathrm{b}} \pm 1.09$ & $66.80^{\mathrm{a}} \pm 0.58$ & $65.40^{\mathrm{a}} \pm 2.39$ & $58.53^{\mathrm{c}} \pm 4.57$ \\
STR $(\%)$ & $82.74^{\mathrm{b}} \pm 0.66$ & $82.76^{\mathrm{b}} \pm 1.82$ & $85.36^{\mathrm{a}} \pm 0.29$ & $82.94^{\mathrm{b}} \pm 1.72$ & $80.59^{\mathrm{c}} \pm 1.46$ \\
\hline WOB $(\%)$ & $75.63^{\mathrm{b}} \pm 1.53$ & $76.57^{\mathrm{b}} \pm 1.35$ & $81.47^{\mathrm{a}} \pm 1.79$ & $80.02^{\mathrm{a}} \pm 1.94$ & $73.18^{\mathrm{c}} \pm 4.72$ \\
\hline ALH $(\mu \mathrm{m})$ & $2.91^{\mathrm{a}} \pm 0.03$ & $2.89^{\mathrm{a}} \pm 0.15$ & $2.92^{\mathrm{a}} \pm 0.08$ & $2.71^{\mathrm{b}} \pm 0.11$ & $2.55^{\mathrm{c}} \pm 0.10$ \\
\hline
\end{tabular}

Explanations: $a, b, c, d-$ means with different superscript letters in the same row differ significantly at $\mathrm{p}<0.05$. VCL - Curvilinear Velocity; VSL - Straight Line Velocity; VAP - Average Path Velocity; LIN - Linearity; STR - Straightness; WOB - Wobble; ALH - Amplitude of Lateral

Tab. 2. Mean values of DNA integrity and viability for frozen-thawed bovine semen in the presence or absence of vitamin $\mathrm{B}_{12}(\overline{\mathrm{x}} \pm \mathrm{SD} ; \mathbf{n}=12)$ obtained by flow cytometry

\begin{tabular}{|c|c|c|c|c|c|}
\hline \multirow{2}{*}{ Parameter } & \multirow{2}{*}{ Control } & \multicolumn{4}{|c|}{ Vitamin $B_{12}$} \\
\hline & & $1.5 \mathrm{mg} / \mathrm{mL}$ & $2.5 \mathrm{mg} / \mathrm{mL}$ & $3.5 \mathrm{mg} / \mathrm{mL}$ & $5.0 \mathrm{mg} / \mathrm{mL}$ \\
\hline Viability (\%) & $34.30^{\mathrm{bc}} \pm 0.065$ & $40.03^{\mathrm{ab}} \pm 0.050$ & $44.09^{\mathrm{a}} \pm 0.034$ & $40.45^{\mathrm{ab}} \pm 0.051$ & $29.04^{c} \pm 0.012$ \\
\hline DNA integrity (\%) & $89.35^{\mathrm{b}} \pm 0.022$ & $92.19^{a} \pm 0.028$ & $92.22^{\mathrm{a}} \pm 0.034$ & $92.30^{\mathrm{a}} \pm 0.025$ & $91.29^{\mathrm{ab}} \pm 0.034$ \\
\hline
\end{tabular}

Explanation: $a, b, c, d-$ means with different superscript letters in the same row differ signifi- 
(A)

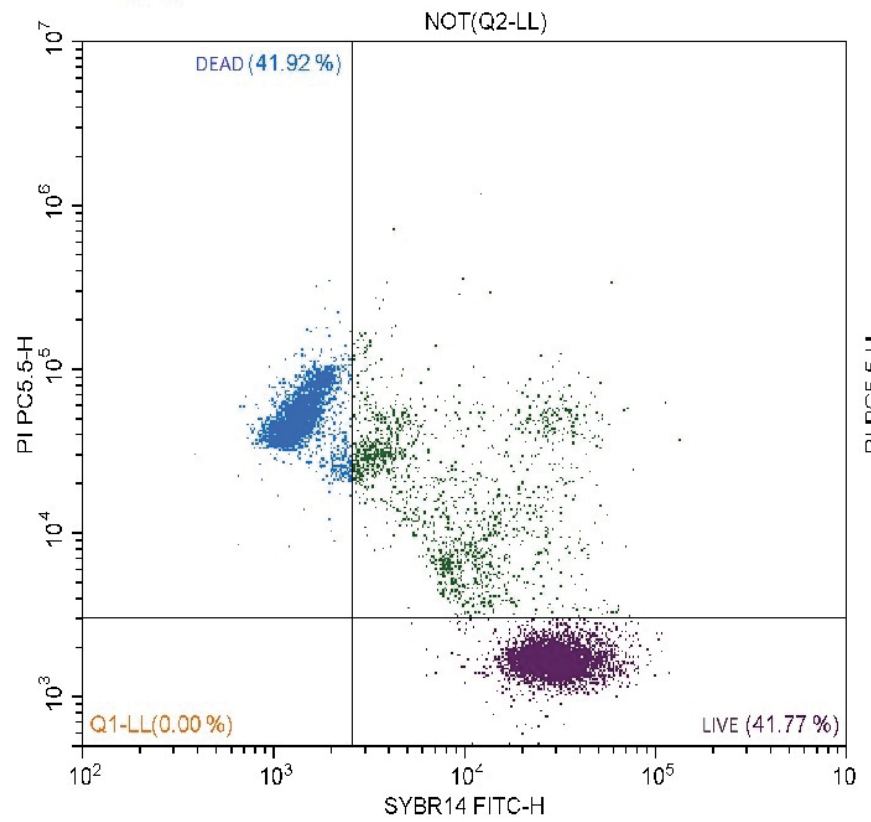

(B)

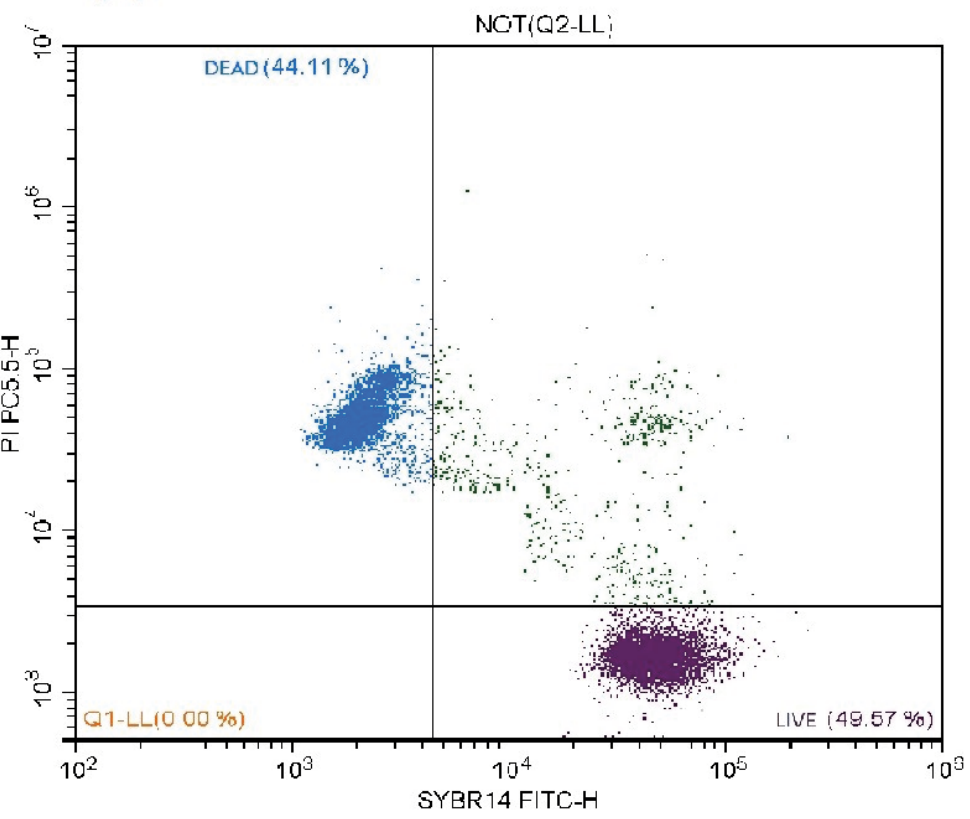

Fig. 1. Randomly selected charts obtained using a flow cytometer from frozen-thawed bovine semen: (A) semen without the addition of vitamin $B_{12}$, (B) semen containing $2.50 \mathrm{mg} / \mathrm{mL}$ of vitamin $B_{12}$

Explanations: LIVE - percentage of live spermatozoa; DEAD - percentage of dead spermatozoa; PI - propidium iodide; SYBR-14 - component

reported that semen frozen in extender supplemented with $2.50 \mathrm{mg} / \mathrm{mL}$ of vitamin $B_{12}$ showed a significant improvement in sperm quality during post-thawing. Cyanocobalamin (vitamin $\mathrm{B}_{12}$ ) is active during cellular replication and DNA synthesis, and it is already used as a treatment for male infertility in humans (11). Some clinical observations have indicated vitamin $\mathrm{B}_{12}$ as an important nutrient for maintaining normal fertility in men $(16,27)$. Cai et al. (7) showed that vitamin $B_{12}$ could improve the motility of bovine spermatozoa during the freezing-thawing process, which is consistent with the coenzyme A activity of vitamin $B_{12}$. Similar results were obtained by $\mathrm{Hu}$ et al. (18), who showed that addition of $2.50 \mathrm{mg} / \mathrm{mL}$ vitamin $B_{12}$ significantly improved sperm motility and movement characteristics, and the percentage of spermatozoa. This increase in motility is an important factor affecting fertilization because efficient transport of sperm from the cervix to the oviducts is required for high rates of ovum fertilization (15).

In our study, vitamin $B_{12}$ has probably protected sperm cells from morphological defects. The deleterious effects of cryopreservation were thus decreased and semen quality improved pre and post freezing. Based on the results of this study, it can be concluded that vitamin $B_{12}$ helps to improve the quality of bovine semen after thawing in terms of mobility, viability, and DNA damage. The optimum concentration of vitamin $\mathrm{B}_{12}$ in bull semen freezing extender was determined as $2.50 \mathrm{mg} / \mathrm{mL}$. Our results show that increasing the concentration of vitamin $B_{12}$ (to $5 \mathrm{mg} / \mathrm{mL}$ ) could not improve the motility and viability of spermatozoa before and after freezing.
$\mathrm{Hu}$ et al. (17) reported that a higher concentration of vitamin $B_{12}(3.75 \mathrm{mg} / \mathrm{mL})$ has a debilitating effect on bull spermatozoa. However, the exact mechanism of negative and positive effects of vitamin $B_{12}$ doses on sperm characteristics requires a detailed study to better understand its precise physiological role in reproduction.

In the present study, sperm viability was not affected by the supplementation of $1.50,3.50$, and 5.00 $\mathrm{mg} / \mathrm{mL}$ vitamin $\mathrm{B}_{12}$, but it was significantly increased by the addition of $2.50 \mathrm{mg} / \mathrm{mL}$. Samplaski et al. (30) report that a reduced sperm viability is correlated with a high degree of sperm DNA fragmentation. One of the final steps before spermatozoa death is DNA defragmentation (19). DNA breaks are among primary factors inducing spermatozoa apoptosis $(12,31)$. The literature has demonstrated a clear link between DNA fragmentation and sperm viability (6).

DNA damage in spermatozoa induced by freezing/ thawing needs to be clarified for efficient fertilization success. The conventional semen quality parameters do not provide information on DNA integrity, which is crucial for fertilization stage, embryo development, pregnancy and reproductive outcomes. Thus, the DNA integrity of sperm cells is of crucial importance. In a recent study by Gual-Frau et al. (13), infertile men with varicocele who were administered multivitamin including vitamin $\mathrm{B}_{12}$ at $1 \mu \mathrm{g} /$ day for 3 months showed about $22.1 \%$ lower sperm DNA fragmentation. GualFrau et al. (13) and $\mathrm{Ni}$ et al. (26) showed that men with varicocele had the highest percentage of sperm cells with damaged DNA compared with other infertile groups. In the present study, we found a significantly 
lower percentage of DNA damage in the presence of vitamin $B_{12}$ in comparison with the control group.

Vitamin $\mathrm{B}_{12}$ improves the motility and vitality of spermatozoa after thawing and protects DNA from damage. Thorough field research is still needed to determine how the addition of vitamin $B_{12}$ to semen affects the effectiveness of fertilization.

\section{References}

1. Asadpour R. M, Pourseif M., Moghadam G., Jafari R., Tayefi H., Mahmodi H.: Effect of vitamin $B_{12}$ addition to extenders on some physicochemical parameters of semen in crossbred rams. Afr. J. Biotechnol. 2012, 11, 11741-11745.

2. Bailey J. L., Bilodeau J. F., Cormier N.: Semen cryopreservation in domestic animals: a damaging and capacitating phenomenon. J. Andro. 2000, 21, 1-7.

3. Bailey J. L., Morrier A., Cormier N.: Semen cryopreservation: Successes and persistent problems in farm species. Can. J. Anim. Sci. 2003, 83, 393-401, doi:10.4141/A03-024

4. Biswas D., Bari F. Y., Shamsuddin M., Rahmand M. M., Rahman M. M.: Determination of glycerol percentage for preserving the black Bengal buck (Capra hircus) spermatozoa for long time. Pak. J. Biol. Sci. 2002, 5, 715-718.

5. Boxmeer J. C., Smit M., Weber R. F., Lindemans J., Romijn J. C., Eijkemans M. J., Macklon N. S., Steegers Theunissen R. P.: Seminal plasma cobalamin significantly correlates with sperm concentration in men undergoing IVF or ICSI procedures. J. Androl. 2007, 28, 521-527.

6. Brahem S., Jellad S., Ibala S., Saad A., Mehdi M.: DNA fragmentation status in patients with necrozoospermia. Syst. Biol. Reprod. Med. 2012, 58, 319-323.

7. Cai J. G., Sun S. Q., Wang L. G., Gu H. J.: The effect of adding vitamin $\mathrm{B}_{12}$ in sperm diluter on quality of bull's straw frozen sperm. J. Liaoning Agricult. Coll. 2004, 6, 10-11.

8. Chen Q. X., Mei J., Ng V., Chia S. E., Ling W. H., Ong C. N.: Semen folate, vitamin B12 and reactive oxygen species and their relationships with sperm parameters. Acta Nutrimenta Sinica. 2001a, 23, 160-163.

9. Chen Q. X., Ng V., Mei J., Chia S. E., Tay S. K., Ling W. H., Ong C. N.: Comparison of seminal vitamin B12, folate reactive oxygen species and various sperm parameter between fertile and infertile males. J. Hyg. Res. 2001b, $30,80-82$.

10. El-Darawany A. A.: Improving semen quality of heat stressed rams in Egypt. Indian J. Anim. Sci. 1999, 69, 1020-1023.

11. Eskenazi B., Kidd A. S., Marks A. R., Sloter E., Block G., Wyrobek A. J. Antioxidant intake is associated with semen quality in healthy men. Hum. Reprod. 2005, 20, 1006-1012.

12. Gandini L., Lombardo F., Paoli D., Caponecchia L., Familiari G., Verlengia C. Study of apoptotic DNA fragmentation in human spermatozoa. Hum. Reprod 2000, 15, 830-839.

13. Gual-Frau J., Abad C., Amengual M. J., Hannaoui N., Checa M. A., RibasMaynou J., Lozano I., Nikolaou A., Benet J., Garcia-Peiro A., Prats J.: Oral antioxidant treatment partly improves integrity of human sperm DNA in infertile grade Ivaricocele patients. Hum. Fertil. 2015, 18, 225-229.

14. Ha F., Zhao Y. Z.: Vitamin B complex as a complement in the thawing dilutions of the ram semen. China Herbivores. 2003, 23, 19-20. Article in Chinese with an abstract in English.

15. Hawk H. W., Conley H. H., Cooper B. S.: Number of sperm in the oviducts, uterus, and cervix of the mated ewe as affected by exogenous estradiol. J. Anim. Sci. 1978, 46, 1300-1308.

16. Hirwe R., Jathar V. S., Desai S., Satoskar R. S.: Vitamin B12 and potential fertility in male lactovegetarians. J. Biosoc. Sci. 1976, 8, 221-227.

17. Hu J. H., Tian W. Q., Zhao X. L., Zan L. S., Xin Y. P., Li Q. W.: The cryoprotective effects of vitamin B12 supplementation on bovine semen quality. Reprod. Domest. Anim. 2011, 46, 66-73.

18. Hu J. H., Li Q. W., Chen Y. L., Jiang Z. L., Jia Y. H., Wang L. Q., Ou B. B. Effects of addition of vitamin B12 to the extender on post-thaw motility, acrosome morphology, and plasma membrane integrity in bull semen. Turk. J. Vet. Anim. Sci. 2009, 33, 379-384.

19. Irvine D. S., Macleod I. C., Templeton A. A., Masterton A., Taylor A.: A prospective clinical study of the relationship between the computer-assisted assessment of human semen quality and the achievement of pregnancy in vivo. Hum. Reprod. 1994, 9, 2324-2334.

20. Januskauskas A., Johannisson A., Rodriguez-Martinez H.: Subtle membrane changes in cryopreserved bull semen in relation with sperm viability, chromatin structure, and field fertility. Theriogenology 2003, 60, 743-758.

21. Jeyendran R. S., van der Ven H. H., Perez-Pelaez M., Crabo B. G., Zaneveld L. J. D.: Development of an assay to assess the functional integrity of the human sperm membrane and its relationship to other semen characteristics. J. Reprod. Fertil. 1984, 70, 219-228.

22. Juanchi X., Albarran G., Negron-Mendoza A.: Radiolysis of cyanocobalamin (vitamin B12). Radiat. Phys. Chem. 2000, 57, 337-339.

23. Maxwell W. M. C., Landers A. J., Evans G.: Survival and fertility of ram spermatozoa frozen in pellets, straws and mini tubes. Theriogenology 1995 , 43, 1201-1210

24. Meyers $S$. A.: Spermatozoal response to osmotic stress. Anim. Reprod. Sci. 2005, 89, 57-64.

25. Morris I. D., Ilott S., Dixon L., Brison D. R.: The spectrum of DNA damage in human sperm assessed by single cell gel electrophoresis (Comet assay) and its relationship to fertilization and embryo development. Hum. Reprod. 2002, 17, 990-998

26. Ni K., Steger K., Yang H., Wang H., Hu K., Zhang T., Chen B.: A comprehensive investigation of sperm DNA damage and oxidative stress injury in infertile patients with subclinical, normozoospermic, and astheno/oligozoospermic clinical varicocoele. Andrology 2016, 4, 816-824.

27. Pardanani D. S., Kher Y. R., Mahendrakar M. N., Kirtane S. T., Jayatilak $P$. G.: Effects of testosterone-vitamin B12 (Aquaviron B12) therapy in cases of oligospermia. Indian J. Surg. 1972, 34, 89-96.

28. Pena F. J., Rodriguez-Martinez H., Tapia J. A., Ortega-Ferrusola C., GonzalezFernandez L., Macias-Garcia B.: Mitochondria in mammalian sperm physiology and pathology: a review. Reprod. Dom. Anim. 2009, 44, 345-349.

29. Rasul Z., Anzar M., Jalali S., Ahmad N.: Effect of buffering systems on post-thaw motion characteristics, plasma membrane integrity, and acrosome morphology of buffalo spermatozoa. Anim. Reprod. Sci. 2000, 59, 31-41.

30. Samplaski M. K., Dimitromanolakis A., Lo K. C., Grober E. D., Mullen B., Garbens $A$.: The relationship between sperm viability and DNA fragmentation rates, Reprod. Biol. Endocrinol. 2015, 13, 42.

31. Shen H. M., Dai J., Chia S. E., Lim A., Ong C. N.: Detection of apoptotic alterations in sperm in subfertile patients and their correlations with sperm quality. Hum. Reprod. 2002, 17, 1266-1273.

32. Watanabe M., Kikawada T., Okuda T.: Increase of internal ion concentration triggers trehalose synthesis associated with cryptobiosis in larvae of Polypedilum vanderplanki. J. Exp. Biol. 2003, 206, 2281-2286.

33. Watson P. F.: The causes of reduced fertility with cryopreserved semen. Anim. Reprod. Sci. 2000, 60-61, 481-492.

Corresponding author: Alicja Mizera MSc, ul. Chełmońskiego 38C, 51-630 Wrocław; e-mail: alicja.mizera@upwr.edu.pl 